\title{
Demographic Factors Affecting The Educational Level Of The South Atlantic States\#
}

\author{
LEON F. BOUVIER* \\ and \\ EDWARD E. CAHILL**
}

In recent years much has been written about the "New South." Not only have numerous changes in social attitudes and practices occurred, but the area is witnessing tremendous population growth. Since 1970 the region has had the most rapid rate of growth of the four regions of the nation. (Bureau of the Census, 1973) There is much speculation on the effects of this large in-migration. In the past such movements have resulted in increasing the number of better educated as well as contributing to other socioeconomic changes. To be sure, many other factors are involved in the dramatic changes that have been taking place in the South. Nevertheless, net migration warrants special investigation to determine what effect it has had on the educational level of the region itself.

From data gathered for the 1940 Census it was demonstrated that the South benefitted educationally from net migration. Johnson concluded that "the South tended to increase the educational quality of its male population aged 25-34 in the period 1935-1940 through selection trends present in the differential migration data." (Johnson, 1955:291) Between 1940 and 1950 there was more evidence of educational changes resulting from net migration. Hamilton found that "in 1950 the South had more population in the 5-8 grades and in the high school categories and less in the 1-4 grades and college categories than would have been the case had not migration occurred." (Hamilton, 1959:40) Summarizing data from various Census sources for the periods 1935-1940, 1949-1950, and 1955-1960, Shryock and Nam noted that "interregional migration has had only a relatively slight net effect on the educational structure of the South and that that effect has been favorable." (Shryock and Nam, 1965:310)

In analyzing the effects of migration of nonwhites on the educational level of the East South Central Division, Price found that between 1955 and 1960 the out-migration of nonwhite males 25-29 reduced the median level of education by three-tenths of a year, and in-migration during the same period raised the median one-tenth of a year, resulting in a net decrease of about two-tenths of a year. (Price, 1965) Using similar data, Folger and Nam concluded that for the adult

\# The research on which this paper is based was funded by the National Science Foundation, Research Applied to National Needs, under the project title "Population Redistribution: A Challenge for Policy and Planning" conducted at the University of Georgia, Athens, Georgia.

*Associate Professor of Sociology, University of Rhode Island.

** Professor of Sociology and Anthropology, University of Tennessee at Chattanooga. 
population "only the movement to the South Atlantic Division had any effect on the educational attainment of the people in the divisions; and it was small-adding only one-tenth of a year to the educational level." (Folger and Nam, 1967: 185)

These studies suggest that the South had benefitted from net migration over the period 1935 to 1960. However, because of counter streams in which both the in-migrants and the out-migrants were likely to be better educated than the native-born residents of the South, the improvement was small. Whether these positive changes have continued to 1970 as a result of increased growth through net in-migration remains to be seen.

Depending on the definition of the "South" different results may be obtained. This report is an analysis of migration and educational attainment in the South Atlantic Division concentrating on the 1965-1970 period. The census division is extremely heterogeneous including the so-called border states of Maryland, Delaware, and West Virginia, the District of Columbia and its suburbs, and the booming state of Florida. It nevertheless perhaps best reflects the so-called New South and as such serves as a good indicator of the changes that are occurring in the region generally.

Investigation focuses first on the changes in educational attainment that have occurred between 1960 and 1970 in the South Atlantic and how these compare with those of other divisions. Second, the effect of net migration on the educational attainment of the division is analyzed. Third, the relative effects of other demographic factors affecting educational attainment levels are considered.

\section{Educational Attainment}

There was marked improvement in the educational level of the adult population (ages 25 years and over) during the 1960's in the South Atlantic Division as well as in the nation. The proportion completing college in the South Atlantic Division increased by almost 40 percent with a 28.3 percent decrease in the proportion having only an elementary school education or less. Increases in the proportion completing high school were substantial in the three border states, but less so in the more southeasterly states. By 1970 only in the Carolinas was the proportion with high school education less than 40 percent. The progress in the number of college graduates was equally remarkable, most states registering increases of well over 25 percent.

Despite these educational gains the South Atlantic Division has not improved its position vis-a-vis the other divisions of the nation. Four other areas had greater proportional increases in the number of college graduates and the national increase of 40.3 percent was greater than that of the South Atlantic Division. Six divisions had greater proportional decreases among those with only eight grades or less completed, compared with a 28.3 percent decrease in the South Atlantic. Thus, while marked progress did occur in the South Atlantic states between the two periods, it merely reflects the national pattern and no relative improvement is noted (Table 1). 
TABLE 1

Percent of Population, 25 Years Old and Over, Completing Designated Years of School by Division in 1960 and 1970.

$\begin{array}{lcc} & \text { High School } & \text { College } \\ 8 \text { Years } & 4 \text { years and } & 4 \text { years } \\ \text { or less } & \text { over } & \text { \& over }\end{array}$

New England

$\begin{array}{lrrr}1960 & 35.1 & 44.6 & 8.4 \\ 1970 & 24.6 & 56.4 & 12.1 \\ \% \text { Change } & -30.7 & 26.5 & 44.0\end{array}$

Middle Atlantic

$\begin{array}{lrrr}1960 & 39.7 & 39.9 & 8.0 \\ 1970 & 28.3 & 51.9 & 10.9 \\ \% \text { Change } & -28.7 & 30.1 & 36.3\end{array}$

East North Central

$\begin{array}{lrrr}1960 & 38.5 & 41.2 & 6.9 \\ 1970 & 26.8 & 53.0 & 9.5 \\ \% \text { Change } & -30.4 & 28.6 & 37.7\end{array}$

West North Central

$\begin{array}{lrrr}1960 & 41.0 & 42.9 & 6.8 \\ 1970 & 29.3 & 55.2 & 9.8 \\ \text { \% Change } & -28.5 & 28.7 & 44.1\end{array}$

South Atlantic

$\begin{array}{lrrr}1960 & 45.3 & 36.6 & 7.6 \\ 1970 & 32.5 & 46.1 & 10.5 \\ \% \text { Change } & -28.3 & 26.0 & 38.2\end{array}$

East South Central

$\begin{array}{lrrr}1960 & 53.1 & 29.5 & 5.4 \\ 1970 & 40.2 & 40.6 & 7.7 \\ \% \text { Change } & -24.3 & 37.6 & 42.3\end{array}$

West South Central

$\begin{array}{ll}1960 & 44.2 \\ 1970 & 32.7\end{array}$

37.2

7.4

$46.2 \quad 10.0$

$\begin{array}{llll}\% & \text { Change } & -26.0 & 24.2\end{array}$

Mountain

$\begin{array}{lrrr}1960 & 31.2 & 49.7 & 9.3 \\ 1970 & 21.5 & 61.3 & 12.9 \\ \% \text { Change } & -31.1 & 23.3 & 38.7\end{array}$

Pacific

$\begin{array}{lrrr}1960 & 28.9 & 51.1 & 9.6 \\ 1970 & 19.9 & 62.5 & 13.2 \\ \% \text { Change } & -31.1 & 22.3 & 37.5\end{array}$

SOURCE: Derived from U.S. Bureau of Census, Detailed Characteristics, PC (1)-D, individual state volumes, 1970, Table 148; and Characteristics of the Population, Part 1, 1960, Tables 102 and 103. 
Although the proportion of those completing high school has increased among these states for the decade, it is still less than the national proportion. Considering the white population, only Delaware now ranks higher than it did in 1960. For the black population only Georgia and Florida rank higher. Similarly for the proportion with college education only Maryland, Virginia, and Georgia improved their ranking within the white population. The only southern states to improve significantly their overall rank in the proportion with a college education are Georgia, rising from 42nd to 34th, and Maryland, moving from ninth to fourth (Table 2).

This failure to register any relative gain in national ranking while significant improvement in education occurred raises two questions: What are the causes of the improvement; and why the lack of relative progress?

\section{Net Migration and Educational Attainment}

Part of the answer to these questions may be found in the special tabulations of the Bureau of the Census published in Lifetime and Recent Migration* which allow the categorization of the population of the South Atlantic Division into four migration statuses. First: the non-migrants are those born in the division and living there in 1965 and 1970; the early migrants, although not born in the division were there in 1965; the return migrants were born in the division but were not residing there in 1965; the recent migrants were neither born there nor in the division five years prior to the census. In addition, it is possible to categorize out-migrants as those who (1) are returning to their division of birth, and (2) those moving from the South Atlantic states but not to their division of birth. This paper concentrates on the "new" in-migrants who comprise both return and recent migrants, the non-migrants, and the recent out-migrants from the area (Table 3).

In 1970 there were about 1.1 million $(1,095,110)$ persons between ages 25 and 64 living in the South Atlantic states not residing there in 1965 . These are the new migrants-over three-quarters of them being recent migrants and the balance return migrants. Approximately 823,000 people left the area in the same fiveyear period. Thus, the South Atlantic Division experienced a net gcin of some 273,000 people between 1965 and 1970. More blacks, however, left the area than entered-some 75,000 out-migrating and 60,000 entering. For the white population, there was a net gain of nearly 288,000 persons between ages 25 and 64 .

A number of studies have found that migrants are better educated than nonmigrants at either the place of origin or of destination. (Bowles et al., 1973; Cahill and Bouvier, 1974; Cahill and Pieper, 1974; Lee et al., 1971:26; Long, 1974) The data for the South Atlantic Division strengthen this hypothesis. As noted in Table 4, for the total population 25-64 years, over 25 percent of the new inmigrants had completed college compared with 7.7 percent of the non-migrants. The difference was especially large for males as one-third of the migrants into the area had finished college, while only 8.8 percent of the non-migrants had done so.

*See Tables 12 and 13, PC(2) -2D, Subject Reports, Lifetime and Recent Migration, 1970 Census of Population. U.S. Government Printing Office, Washington, D.C. 
TABLE 2

Percent of Population 25 Years of Age and Over Completing Four Years of High School and Four Years of College by Race: South Atlantic States, 1960 and 1970

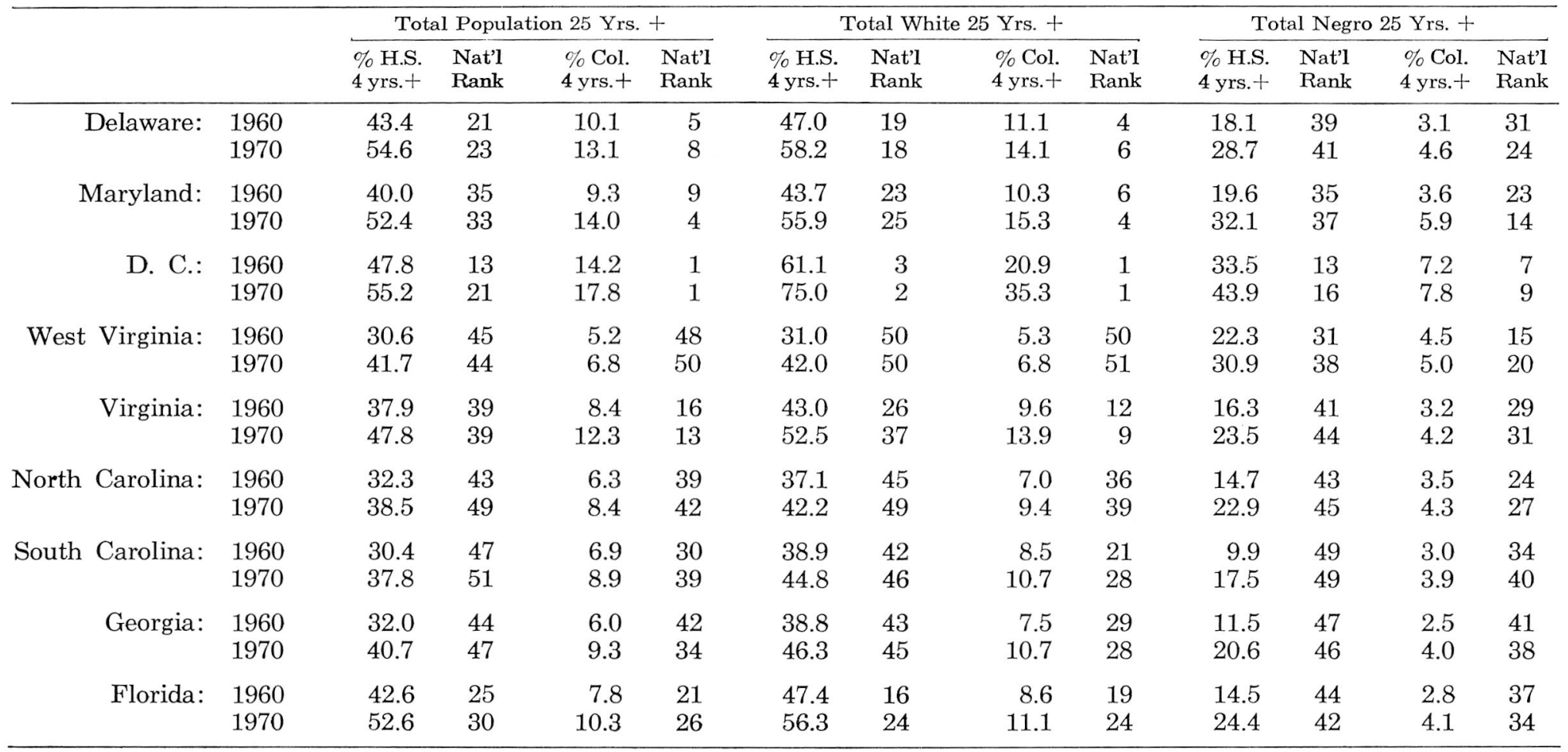

SOURCE: Same as Table 1. 
TABLE 3

Migration of Persons Aged 25-64 Years In and Out of South Atlantic Division: 1965-1970.

\begin{tabular}{crrc}
\hline & In-Migration & Out-Migration & Net Migration \\
\hline TOTAL & $1,095,110$ & 822,564 & 272,546 \\
Male & 552,063 & 444,298 & 107,765 \\
Female & 543,047 & 378,266 & 164,781 \\
NEGRO & 60,563 & 75,438 & $-14,875$ \\
Male & 31,298 & 38,252 & $-6,954$ \\
Female & 29,265 & 37,186 & $-7,921$ \\
\hline
\end{tabular}

SOURCE: U.S. Bureau of Census, Census of Population: 1970, Subject Reports, Final Report, PC (2)-2D, Lifetime and Recent Migration, Tables 12 and 13.

The same is true for the black population as new in-migrants were almost three times as likely to have finished college as were non-migrants.

Out-migrants from the South Atlantic Division are also better educated than non-migrants in the division. About one-quarter of all those leaving between 1965 and 1970 had completed college; more than 30 percent among males. For the black population, out-migrants were also better educated but differences were smaller. Thus, out-migrants as well as in-migrants have completed a significantly higher level of education, as measured by the proportion completing college, than the native-born non-migrants of the division.

Clearly the South Atlantic states benefitted educationally from net migration. Among out-migrants 24.5 percent had completed college; but 25.1 percent of the in-migrants had done so. More important, the number of people moving in was much greater than that moving out. Thus, the South Atlantic Division added 73,230 persons with at least four years of college. Among blacks, out-migrants were more likely to have completed college (13.2 to 12.4 percent) and they were also more numerous than the in-migrants. Through net migration the area lost 2,423 college educated blacks.

Almost half of all the new migrants in the South Atlantic states are under age 35 and it is here that educational differences are most substantial. About 40 percent of all male in-migrants have had four years of college; only about ten percent of the non-migrants. But, over 30 percent of those leaving also had a college education. In the exchange the division benefitted educationally. Indeed, it experienced a net gain of nearly 32,000 college graduates. No less than 43.5 percent of the total increase in the number of college educated migrants consists of people under 35 .

The proportion having completed college is not a comprehensive measure of changes in educational attainment. The differential in number with only an elementary school education is equally important. Here, of course, any numerical gain reflects a decline in overall educational attainment. The South Atlantic Di- 
TABLE 4

Percent Distribution of the Population of South Atlantic Division 25-64 Years Old and 25-34 Years Old with Four Years of College or More by Migration Status, Race and Sex: 1970.

\begin{tabular}{|c|c|c|c|c|c|c|c|c|c|c|}
\hline \multirow{2}{*}{$\begin{array}{c}\text { Age, } \\
\text { Race, } \\
\text { Sex }\end{array}$} & \multirow[b]{2}{*}{$\begin{array}{c}\text { All } \\
\text { Classes }\end{array}$} & \multirow[b]{2}{*}{$\begin{array}{c}\text { Non- } \\
\text { Migrants }\end{array}$} & \multicolumn{5}{|c|}{ IN-MIGRANT } & \multicolumn{3}{|c|}{ OUT-MIGRANT } \\
\hline & & & Total & Early & Total & $\begin{array}{l}\text { 1965-1970 } \\
\text { Return }\end{array}$ & Recent & Total & $\begin{array}{c}\text { 1965-1970 } \\
\text { Return }\end{array}$ & Recent \\
\hline \multicolumn{11}{|c|}{ 25-64 Yrs. } \\
\hline TOTAL & $\begin{array}{c}1,432,756 \\
11.2\end{array}$ & $\begin{array}{c}698,300 \\
7.7\end{array}$ & $\begin{array}{l}734,456 \\
20.5\end{array}$ & $\begin{array}{c}459,611 \\
18.5\end{array}$ & $\begin{array}{l}274,845 \\
25.1\end{array}$ & $\begin{array}{l}45,375 \\
18.6\end{array}$ & $\begin{array}{l}229,470 \\
27.0\end{array}$ & $\begin{array}{l}201,615 \\
24.5\end{array}$ & $\begin{array}{l}65,825 \\
21.6\end{array}$ & $\begin{array}{c}135,790 \\
26.2\end{array}$ \\
\hline Male & $\begin{array}{c}850,690 \\
14.0\end{array}$ & $\begin{array}{c}379,781 \\
8.8\end{array}$ & $\begin{array}{l}470,909 \\
27.0\end{array}$ & $\begin{array}{l}289,155 \\
24.2\end{array}$ & $\begin{array}{c}181,754 \\
32.9\end{array}$ & $\begin{array}{l}29,569 \\
23.5\end{array}$ & $\begin{array}{l}152,185 \\
35.7\end{array}$ & $\begin{array}{c}133,453 \\
30.1\end{array}$ & $\begin{array}{l}44,177 \\
25.7\end{array}$ & $\begin{array}{l}89,276 \\
32.8\end{array}$ \\
\hline Female & $\begin{array}{c}582,066 \\
8.7\end{array}$ & $\begin{array}{c}318,519 \\
6.6\end{array}$ & $\begin{array}{c}263,547 \\
14.3\end{array}$ & $\begin{array}{c}170,456 \\
13.1\end{array}$ & $\begin{array}{l}93,091 \\
17.1\end{array}$ & $\begin{array}{l}15,806 \\
13.4\end{array}$ & $\begin{array}{l}77,285 \\
18.2\end{array}$ & $\begin{array}{l}68,162 \\
18.0\end{array}$ & $\begin{array}{l}21,648 \\
16.5\end{array}$ & $\begin{array}{l}46,514 \\
19.0\end{array}$ \\
\hline NEGRO & $\begin{array}{c}115,650 \\
5.1\end{array}$ & $\begin{array}{l}95,150 \\
4.5\end{array}$ & $\begin{array}{l}20,500 \\
11.4\end{array}$ & $\begin{array}{l}13,136 \\
11.0\end{array}$ & $\begin{array}{l}7,516 \\
12.4\end{array}$ & $\begin{array}{l}3,469 \\
9.5\end{array}$ & $\begin{array}{l}4,047 \\
17.0\end{array}$ & $\begin{array}{l}9,939 \\
13.2\end{array}$ & $\begin{array}{l}1,673 \\
10.8\end{array}$ & $\begin{array}{l}8,266 \\
13.8\end{array}$ \\
\hline Male & $\begin{array}{l}45,421 \\
4.4\end{array}$ & $\begin{array}{l}35,051 \\
3.7\end{array}$ & $\begin{array}{l}10,370 \\
11.4\end{array}$ & $\begin{array}{l}6,389 \\
10.6\end{array}$ & $\begin{array}{l}4,133 \\
13.2\end{array}$ & $\begin{array}{l}1,908 \\
10.3\end{array}$ & $\begin{array}{l}2,225 \\
17.5\end{array}$ & $\begin{array}{l}4,887 \\
12.8\end{array}$ & $\begin{array}{l}795 \\
9.5\end{array}$ & $\begin{array}{c}4,092 \\
13.7\end{array}$ \\
\hline Female & $\begin{array}{l}70,229 \\
5.6\end{array}$ & $\begin{array}{l}60,099 \\
5.3\end{array}$ & $\begin{array}{l}10,130 \\
11.5\end{array}$ & $\begin{array}{l}6,747 \\
11.4\end{array}$ & $\begin{array}{l}3,383 \\
11.6\end{array}$ & $\begin{array}{l}1,561 \\
8.6\end{array}$ & $\begin{array}{l}1,822 \\
16.6\end{array}$ & $\begin{array}{l}5,052 \\
13.6\end{array}$ & $\begin{aligned} 878 & { }^{8.4}\end{aligned}$ & $\begin{array}{l}4,174 \\
13.9\end{array}$ \\
\hline \multicolumn{11}{|l|}{ 25-34 Yrs. } \\
\hline TOTAL & $\begin{array}{c}460,309 \\
13.1\end{array}$ & $\begin{array}{c}228,900 \\
9.2\end{array}$ & $\begin{array}{l}261,409 \\
25.5\end{array}$ & $\begin{array}{c}107,191 \\
19.9\end{array}$ & $\begin{array}{c}154,218 \\
31.9\end{array}$ & $\begin{array}{l}25,874 \\
21.6\end{array}$ & $\begin{array}{c}128,344 \\
35.3\end{array}$ & $\begin{array}{c}122,337 \\
26.5\end{array}$ & $\begin{array}{l}40,838 \\
22.9\end{array}$ & $\begin{array}{l}81,499 \\
28.8\end{array}$ \\
\hline Male & $\begin{array}{l}259,919 \\
17.0\end{array}$ & $\begin{array}{l}126,274 \\
10.6\end{array}$ & $\begin{array}{c}163,645 \\
32.2\end{array}$ & $\begin{array}{l}64,386 \\
25.0\end{array}$ & $\begin{array}{l}99,259 \\
39.6\end{array}$ & $\begin{array}{l}16,938 \\
26.4\end{array}$ & $\begin{array}{l}82,321 \\
44.2\end{array}$ & $\begin{array}{l}78,814 \\
30.5\end{array}$ & $\begin{array}{l}25,599 \\
25.2\end{array}$ & $\begin{array}{l}51,215 \\
34.3\end{array}$ \\
\hline Female & $\begin{array}{c}200,390 \\
11.1\end{array}$ & $\begin{array}{c}102,626 \\
7.9\end{array}$ & $\begin{array}{l}97,764 \\
19.0\end{array}$ & $\begin{array}{l}42,805 \\
15.1\end{array}$ & $\begin{array}{l}54,959 \\
23.6\end{array}$ & $\begin{array}{l}8,936 \\
16.0\end{array}$ & $\begin{array}{l}46,023 \\
26.0\end{array}$ & $\begin{array}{l}43,523 \\
21.4\end{array}$ & $\begin{array}{l}13,239 \\
19.2\end{array}$ & $\begin{array}{l}30,284 \\
22.6\end{array}$ \\
\hline NEGRO & $\begin{array}{l}39,145 \\
6.0\end{array}$ & $\begin{array}{c}30,673 \\
5.2\end{array}$ & $\begin{array}{l}8,472 \\
12.9\end{array}$ & $\begin{array}{l}3,939 \\
12.1\end{array}$ & $\begin{array}{l}4,533 \\
13.7\end{array}$ & $\begin{array}{l}1,962 \\
10.4\end{array}$ & $\begin{array}{l}2,571 \\
18.1\end{array}$ & $\begin{array}{l}7,328 \\
15.8\end{array}$ & $\begin{array}{l}1,246 \\
13.4\end{array}$ & $\begin{array}{l}6,082 \\
16.4\end{array}$ \\
\hline Male & $\begin{array}{l}15,634 \\
5.2\end{array}$ & $\begin{array}{c}11,293 \\
4.3\end{array}$ & $\begin{array}{l}4,341 \\
13.1\end{array}$ & $\begin{array}{l}1,859 \\
11.6\end{array}$ & $\begin{array}{l}2,482 \\
14.5\end{array}$ & $\begin{array}{l}1,158 \\
12.0\end{array}$ & $\begin{array}{l}1,324 \\
18.0\end{array}$ & $\begin{array}{l}3,426 \\
14.1\end{array}$ & $10.3^{542}$ & $\begin{array}{l}2,884 \\
15.1\end{array}$ \\
\hline Female & $\begin{array}{l}23,511 \\
6.7\end{array}$ & $\begin{array}{l}19,380 \\
6.0\end{array}$ & $\begin{array}{l}4,131 \\
12.7\end{array}$ & $\begin{array}{l}2,080 \\
12.5\end{array}$ & $\begin{array}{l}2,051 \\
12.8\end{array}$ & $\begin{array}{l}804 \\
8.8\end{array}$ & $\begin{array}{l}1,247 \\
18.2\end{array}$ & $\begin{array}{l}3,902 \\
17.4\end{array}$ & $\begin{array}{r}704 \\
16.4^{7}\end{array}$ & $\begin{array}{l}3,198 \\
17.6\end{array}$ \\
\hline
\end{tabular}

SOURCE: U.S. Bureau of the Census, Census of Population: 1970, Subject Reports, PC(2)-2D, Lifetime and Recent Migration, Tables 12 and 13. 
vision gained numerically at both ends of the educational scale. In-migrants had a greater proportion with eight years or less of schooling than did out-migrants (25.0 percent vs. 23.8 percent) resulting in a net gain of 34,860 persons (see Table 5).

A net decrease of 3,318 was noted among persons under age 35, however. As a result, a portion of the educational gain resulting from net in-migration of the college educated was negated by a similar net in-migration of those with only an elementary school education. Merely determining which educational-levels lost or gained population in the five-year period tells little about the overall effect.

With the data from the 1970 Census it is also possible to construct a "model" population for ages 25-64 in which no migration, in- or out-, takes place. It is assumed that no one entered the division and no one left in the 1965-1970 period. The formula is:

$$
\mathrm{P}_{\mathrm{h}}=\mathrm{P}_{\mathrm{r}_{\mathrm{ni}}}-\text { Inmig }_{\mathrm{ni}}+\text { Outmig }_{\mathrm{ni}}
$$

where $\mathrm{h}=$ model population, $\mathrm{r}=$ real population, ni refers to the educational categories. As can be seen from Table 6 the net effect on educational attainment of two opposing migration streams is limited, though the division did benefit somewhat. The real population had slightly more college educated and fewer of the least educated than would the model "no migration" population.

Though the evidence indicates that the division profitted educationally from net migration, its effect on raising the educational attainment level for the total adult population was slight, despite the fact that migration was clearly selective of the better educated. As Folger and Nam have noted: "Even if persons with more education are more likely to move, the effects of this movement may not be very great if the numbers involved are small, or if each migration stream has a return stream which cancels its effects." (Folger and Nam, 1967:179) The latter situation obtained in the South Atlantic states in the 1965-1970 period. However, the effectiveness of the migration tended to increase with educational advancement, again suggesting general improvement for the division. But this should not be exaggerated; the effectiveness ratios remained very low at all educational levels.

\section{Effects of Other Demographic Factors}

The major contributor to the marked increase in educational attainment in the South Atlantic Division was not net migration. Rather, it resulted from natural attrition. In explaining the causes of educational improvement Folger and Nam correctly point out that "the main factor in the increase (in educational attainment) has been the death of older persons, who as a class had lower than average education, and entrance into adulthood of younger persons with higher than average amounts of schooling." (Folger and Nam, 1967:137) In the South Atlantic Division, over 70 percent of the population 25-64 are non-migrants and 
TABLE 5

Percent Distribution of the Population of the South Atlantic Division, 25-64 Years Old, With Eight Years or Less of School, by Migration Status, Race and Sex: 1970

\begin{tabular}{|c|c|c|c|c|c|c|c|c|c|c|}
\hline \multirow{2}{*}{$\begin{array}{l}\text { Sex } \\
\text { and } \\
\text { Color }\end{array}$} & \multirow[b]{2}{*}{$\begin{array}{c}\text { All } \\
\text { Classes }\end{array}$} & \multirow[b]{2}{*}{$\begin{array}{c}\text { Non- } \\
\text { Migrants }\end{array}$} & \multicolumn{5}{|c|}{ IN-MIGRANT } & \multicolumn{3}{|c|}{ OUT-MIGRANT } \\
\hline & & & Total & Early & Total & $\begin{array}{c}\text { 1965-1970 } \\
\text { Return }\end{array}$ & Recent & Total & $\begin{array}{c}\text { 1965-1970 } \\
\text { Return }\end{array}$ & Recent \\
\hline TOTAL & $\begin{array}{c}3,462,381 \\
27.2\end{array}$ & $\begin{array}{c}2,981,447 \\
32.6\end{array}$ & $\begin{array}{c}480,924 \\
13.4\end{array}$ & $\begin{array}{c}316,250 \\
14.7\end{array}$ & $\begin{array}{c}114,684 \\
10.5\end{array}$ & $\begin{array}{l}34,443 \\
14.2\end{array}$ & $\begin{array}{c}80,241 \\
9.4\end{array}$ & $\begin{array}{c}79,824 \\
9.7\end{array}$ & $\begin{array}{c}26,897 \\
8.9\end{array}$ & $\begin{array}{l}52,927 \\
10.2\end{array}$ \\
\hline Male & $\begin{array}{c}1,820,080 \\
29.9\end{array}$ & $\begin{array}{c}1,577,679 \\
36.4\end{array}$ & $\begin{array}{c}242,391 \\
13.9\end{array}$ & $\begin{array}{c}183,803 \\
15.4\end{array}$ & $\begin{array}{l}58,598 \\
10.6\end{array}$ & $\begin{array}{l}18,877 \\
15.0\end{array}$ & $\begin{array}{c}39,721 \\
9.3\end{array}$ & $\begin{array}{l}42,004 \\
9.5\end{array}$ & $\begin{array}{c}14,340 \\
8.3\end{array}$ & $\begin{array}{l}27,664 \\
10.2\end{array}$ \\
\hline Female & $\begin{array}{c}1,642,301 \\
24.7\end{array}$ & $\begin{array}{c}1,403,768 \\
29.1\end{array}$ & $\begin{array}{c}288,533 \\
13.0\end{array}$ & $\begin{array}{c}182,447 \\
14.2\end{array}$ & $\begin{array}{l}56,086 \\
10.3\end{array}$ & $\begin{array}{l}15,566 \\
13.2\end{array}$ & $\begin{array}{c}40,520 \\
9.5\end{array}$ & $\begin{array}{l}37,820 \\
10.0\end{array}$ & $\begin{array}{c}12,557 \\
9.5\end{array}$ & $\begin{array}{l}25,263 \\
10.2\end{array}$ \\
\hline NEGRO & $\begin{array}{c}1,063,430 \\
46.5\end{array}$ & $\begin{array}{c}1,010,284 \\
48.0\end{array}$ & $\begin{array}{l}53,146 \\
29.6\end{array}$ & $\begin{array}{l}41,275 \\
34.6\end{array}$ & $\begin{array}{l}11,871 \\
19.6\end{array}$ & $\begin{array}{l}8,026 \\
21.8\end{array}$ & $\begin{array}{c}3,845 \\
16.2\end{array}$ & $\begin{array}{l}16,207 \\
21.5\end{array}$ & $\begin{array}{l}3,536 \\
22.8\end{array}$ & $\begin{array}{l}12,671 \\
21.2\end{array}$ \\
\hline Male & $\begin{array}{c}538,666 \\
51.6\end{array}$ & $\begin{array}{c}509,615 \\
53.4\end{array}$ & $\begin{array}{l}29,051 \\
31.8\end{array}$ & $\begin{array}{l}22,620 \\
37.8\end{array}$ & $\begin{array}{l}6,431 \\
20.5\end{array}$ & $\begin{array}{l}4,282 \\
23.1\end{array}$ & $\begin{array}{l}2,149 \\
16.8\end{array}$ & $\begin{array}{l}8,355 \\
21.8\end{array}$ & $\begin{array}{l}2,029 \\
24.3\end{array}$ & $\begin{array}{l}6,326 \\
21.2\end{array}$ \\
\hline Female & $\begin{array}{c}524,764 \\
42.3\end{array}$ & $\begin{array}{c}500,669 \\
43.4\end{array}$ & $\begin{array}{l}24,095 \\
27.2\end{array}$ & $\begin{array}{l}18,655 \\
31.5\end{array}$ & $\begin{array}{c}5,440 \\
18.6\end{array}$ & $\begin{array}{l}3,744 \\
20.4\end{array}$ & $\begin{array}{c}1,696 \\
15.5\end{array}$ & $\begin{array}{l}7,865 \\
21.1\end{array}$ & $\begin{array}{l}1,520 \\
21.4\end{array}$ & $\begin{array}{l}6,345 \\
21.1\end{array}$ \\
\hline
\end{tabular}

SOURCE: Same as Table 4. 


\section{TABLE 6}

Percent Distribution of Persons 25-64 by Educational Attainment in No Migration "Model" and Real Populations for South Atlantic Division: 1970

\begin{tabular}{ccc}
\hline Model & Years of Education & Real \\
& TOTAL \\
27.5 & 8 or less & 27.2 \\
22.9 & $1-3$ High School & 22.8 \\
28.6 & $4 \quad$ High School & 28.6 \\
10.1 & $1-3$ College & 10.2 \\
10.9 & $4 \quad$ or more College & 11.2 \\
& \\
46.4 & NEGRO \\
25.4 & 1-3 High School & 46.5 \\
18.4 & 4 High School & 25.4 \\
4.6 & $1-3$ College & 18.4 \\
5.2 & 4 or more College & 4.6 \\
\hline
\end{tabular}

another 19.6 percent are early migrants. Thus, recent net migration accounts for less than ten percent of the total population. Dramatic changes in education cannot be expected merely from net migration.

The effect of natural attrition on the educational attainment of the population between ages 25 and 64 can be determined. Natural attrition results from the loss of those aged 55-64 in 1960 and their replacement by the non-migrants and early migrants aged 25-34 in 1970. Attrition also occurs through mortality, but such rates are so low as to preclude their being major contributors to improved educational levels for the area.

Between 1960 and 1970, the South Atlantic Division added about 525,000 college educated persons. Of this total, five-year net migration accounted for 14.0 percent $(73,230)$. Among those "leaving" due to old age, 119,000 had a college education. Among non- and early migrants entering the population category, 336,000 had completed college - a net balance of 217,000 or 41 percent of the total increase in the number of residents with at least four years of college (Table 7). The remaining 45 percent is accounted for by earlier migration or return migration (pre-1965), mortality differentials and individual education progress. It is not possible to adequately estimate mortality differentials by educational attainment. Further, the actual number leaving the area between 1960 and 1965 remains undetermined. Thus, conclusions are necessarily limited to ascertaining the proportion of the progress attributable to five-year net migration and natural attrition. 
TABLE 7

Number and Percent Gains and Losses through "Natural Attrition" by Divisions: 1960-70

\begin{tabular}{|c|c|c|c|c|c|c|c|c|c|c|}
\hline \multirow[b]{2}{*}{ DIVISION } & \multicolumn{5}{|c|}{ 1955-60 Total Population Aged 55-64 Years } & \multicolumn{5}{|c|}{$\begin{array}{l}\text { 1965-70 Non-Migrant and Early Migrant } \\
\text { Population Aged 25-34 Years }\end{array}$} \\
\hline & $\begin{array}{c}\text { Colle } \\
4 \text { Yrs } \\
\text { Number }\end{array}$ & + & $\begin{array}{l}\text { Scho } \\
8 \text { Years } \\
\text { Number }\end{array}$ & Less & $\begin{array}{l}\text { Ratio* } \\
\text { Col/Ele }\end{array}$ & $\begin{array}{r}\text { Colleg } \\
4 \text { Year } \\
\text { Number }\end{array}$ & $+\%$ & \multicolumn{2}{|c|}{$\begin{array}{c}\text { School } \\
8 \text { Years \& Less }\end{array}$} & $\begin{array}{l}\text { Ratio* } \\
\text { Col/Ele }\end{array}$ \\
\hline NEW ENGLAND & 61,329 & 6.1 & 494,325 & 49.5 & 12 & 163,572 & 14.8 & 108,748 & 9.9 & 150 \\
\hline MIDDLE ATLANTIC & 193,884 & 5.7 & $2,000,061$ & 58.8 & 10 & 533,734 & 14.4 & 353,074 & 9.5 & 151 \\
\hline EAST NORTH CENTRAL & 167,882 & 5.3 & $1,852,538$ & 58.0 & 9 & 505,418 & 12.4 & 332,386 & 8.2 & 152 \\
\hline WEST NORTH CENTRAL & 73,116 & 5.1 & 829,841 & 57.3 & 9 & 208,085 & 13.6 & 118,010 & 7.7 & 176 \\
\hline SOUTH ATLANTIC & 118,957 & 5.8 & $1,235,928$ & 60.3 & 10 & 336,091 & 11.1 & 457,365 & 15.1 & 73 \\
\hline EAST SOUTH CENTRAL & 37,367 & 3.8 & 652,640 & 66.9 & 6 & 115,624 & 9.3 & 242,832 & 19.5 & 48 \\
\hline WEST SOUTH CENTRAL & 71,217 & 5.3 & 818,876 & 58.9 & 9 & 237,826 & 12.5 & 185,390 & 9.7 & 128 \\
\hline MOUNTAIN & 35,237 & 7.2 & 233,769 & 47.3 & 15 & 100,364 & 13.9 & 66,868 & 9.3 & 150 \\
\hline PACIFIC & 124,711 & 7.2 & 804,287 & 45.9 & 16 & 400,600 & 15.2 & 176,186 & 6.7 & 227 \\
\hline
\end{tabular}

*Number of $\frac{\text { College graduates }}{8 \text { years elementary school or less }} \times 100$.

SOURCE: Same as Table 4 . 


\section{Comparison with the Nation}

Although the South Atlantic Division exhibited rapid progress in education during the 1960's it did not keep pace with the nation. Other divisions apparently benefitted more from either net migiation or natural attrition, but not substantially more from net migration as did the South Atlantic. The South, as a region, has historically been the educational beneficiary of interdivisional migration. This remained true in 1970 for the South Atlantic Division.

The differential educational contribution of natural attrition by divisions best explains the failure of the South Atlantic Division to improve its relative position. Natural attrition contributes most to educational improvement if those leaving the system (i.e., the elderly) are relatively poorly educated while those entering (i.e., the young non- and early migrants) are well educated. Additionally, the numerical difference between the two is important.

The overall educational attainment of the "exiting" South Atlantic group is among the lowest in the nation. Only the East South Central states have a greater proportion with but an elementary school education. At the other educational extreme, the division did fairly well, only the western divisions and New England having greater proportions of their elderly populations with college education. The "loss" of over one and a quarter million poorly educated residents through natural attrition contributed to an improvement of the educational level of the area. However, it is in the "entering" group (25-34 years in 1970) that the division loses out in comparison to the remainder of the nation. No division outside the South has a greater proportion of the least educated or a smaller proportion of the best educated. In the South Atlantic Division 457,365 persons with no more than eight grades of schooling entered the 25-64 years age group. This represents 3.6 percent of the total 1970 adult population. But only 336,091, or 2.6 percent, entered who were college graduates. On the other hand, in New England for example, the 108,748 poorly educated and the 163,572 well educated young non- or early migrant adults represented 2.2 and 3.3 percent, respectively, of that division's 1970 population. The South Atlantic and East South Central Divisions both had significantly larger populations of the least educated in the 25-64 age group in 1970. All other divisions had more of the college educated. To a considerable extent this explains the failure of the area to improve its overall educational position despite the fact that it benefits more through net migration than most other divisions. Very simply, the South Atlantic Division has a larger supply of less educated non- or early migrants ready to enter adulthood than other divisions (Table 8).

This infusion of less educated young adults contributes significantly to the South's failure to "catch up" to the rest of the nation education-wise. The South has profitted from net migration. It is clearly becoming an ever more attractive place of destination for non-southern college graduates. Thus, a large proportion of the improvement in overall education is due to net in-migration of the better educated. The combination of a relatively less educated non-migrant (or early migrant) group and a relatively well educated in-migrant group is contributing to some unusual distributions by education. As a result of the selectivity 
TABLE 8

Percent of Population Aged 19-24 Years Enrolled in School - by U.S. Census Division: 1970

\begin{tabular}{lcccccr}
\hline Division & 19 & 20 & 21 & 22 & 23 & 24 \\
\hline New England & 55.1 & 40.7 & 33.6 & 20.3 & 14.2 & 11.6 \\
Middle Atlantic & 49.9 & 36.1 & 29.8 & 17.8 & 13.3 & 11.1 \\
East North Central & 47.5 & 35.1 & 29.2 & 18.9 & 13.3 & 11.0 \\
West North Central & 50.4 & 38.6 & 31.7 & 20.2 & 13.5 & 10.9 \\
South Atlantic & 42.4 & 27.7 & 21.9 & 14.5 & 10.3 & 8.3 \\
East South Central & 41.6 & 28.5 & 23.4 & 15.5 & 10.4 & 8.3 \\
West South Central & 45.3 & 31.2 & 25.5 & 17.4 & 11.9 & 9.5 \\
Mountain & 50.2 & 35.8 & 30.3 & 23.0 & 17.9 & 14.5 \\
Pacific & 46.8 & 33.5 & 27.8 & 22.3 & 18.4 & 15.8 \\
U.S. & 47.2 & 33.6 & 27.7 & 18.5 & 13.5 & 11.1 \\
\hline
\end{tabular}

SOURCE: U.S. Bureau of Census, Census of Population: 1970, Detailed Characteristics, PC (1)-D1, U.S. Summary.

that has been going on for a few decades, 20 percent of all the college educated people in the South Atlantic states are either recent or return migrants. Less than half are non-migrants. Over one-third of all the males 25-34 who have completed college are new migrants into the area. On the other hand, less than 15 percent of those with eight grades or less of school are newcomers. This is leading to a situation in which a large majority of the least educated will be area born while a substantial proportion of the best educated will be new residents of the division.

\section{Future Possibilities}

The over-representation of the better educated among those migrating into the South will undoubtedly continue into the foreseeable future. Certainly the "New South" will remain an inviting place for the college educated of other regions of the nation. But what are the future prospects for drastically improving the educational attainment of the non-migrant population of the area? If the data on school enrollment summarized in Table 8 are indicative of the future, there seems to be little hope that the South Atlantic Division will "catch up" through natural attrition. Indeed, these data consider only the total population and do not separate by race or sex. Nevertheless, when looking at the South Atlantic area and inquiring if its educational level will soon be equal to that of the nation, the answer must be negative unless net migration continues to bring into the area better educated newcomers in increasing numbers. There is a New South emerging and it has progressed enormously in education. But it remains at the bottom among the regions of the nation despite the impressive schooling of the recent migrants into the area. Only through a dramatic reversal of the historical trend, vis-a-vis the need for maintaining a larger percentage of its young people in secondary school and college and holding them after graduation, can the South hope to achieve parity with the rest of the nation. 


\section{REFERENCES}

Bowles, Gladys K., Lloyd Bacon and Neal Ritchey. 1973. "Educational Attainment," Poverty Dimensions of Rural-to-Urban Migration: A Statistical Report. Chapter 9. Washington, D.C.: U.S. Government Printing Office.

Bureau of the Census. 1973. Current Population Reports. Series P-25, No. 508 (November). Washington, D.C.: U.S. Government Printing Office.

Cahill, Edward E. and Leon Bouvier. 1974a. "The Effects of Migration on Educational Attainment in New England." New England Journal of Business and Economics. 1 (Fall).

and Hanns Pieper. 1974b. "Educational Achievement of Recent Migrants from Nonmetropolitan Areas." Mimeo. paper presented at the Annual Meeting of the Rural Sociological Society. (August). Montreal, Canada.

Folger, John and Charles Nam. 1967. Education of the American Population. (A 1960 Census Monograph). Washington, D.C.: U.S. Government Printing Office.

Hamilton, C. Horace. 1959. "Educational Selectivity of Net Migration From the South." Social Forces. 38 (October): 40 .

Johnson, Elmer. 1955. "Methodological Note on Measuring Selection in Differential Migration." Social Forces. 33 (March): 291 .

Lee, Everett S., J. C. Bresee, K. P. Nelson and D. A. Patterson. 1971. An Introduction to Urban Decentralization Research. Oak Ridge, Tennessee: Oak Ridge National Laboratory.

Long, Larry H. 1974. "Poverty Status and Receipt of Welfare Among Migrants and Nonmigrants in Large Cities." American Sociological Review. 39 (February).

Price, Daniel. 1965. "The Effects of Migration on Educational Level of Nonwhites in a Southern Area." Paper presented at the Population Association of America Meeting.

Shryock, Henry and Charles Nam. 1965. "Educational Selectivity of Interregional Migration." Social Forces. 43 (March): 310. 